\title{
Antibacterial activity of Rhus succedanea Var. Himalaica
}

\author{
Shafqat Ali Khan ${ }^{1}$, Muhammad Ibrar ${ }^{1}$, Barkatullah $^{2}$ and Sami Ullah ${ }^{1 *}$ \\ 1. Department of Botany, University of Peshawar-Pakistan \\ 2. Department of Botany, Islamia College University Peshawar-Pakistan \\ *Corresponding author's email: sami_jan69@yahoo.com \\ Citation \\ Shafqat Ali Khan, Muhammad Ibrar, Barkatullah and Sami Ullah. Antibacterial activity of Rhus succedanea Var. \\ Himalaica.. Pure and Applied Biology. Vol. 6, Issue 2, pp718-724. http://dx.doi.org/10.19045/bspab.2017.60076 \\ Received: 14/02/2017 Revised: 17/05/2017 \\ Accepted: 28/05/2017 Online First: 02/06/2017
}

\section{Abstract}

The antibacterial activity of leaf and root ethanolic extracts as well as crude alkaloids and flavonoids from both the parts of Rhus succedanea were carried against bacterial strains viz. Staphylococcus aureus, Clavibacter michiganensis, Proteus vulgaris and Xanthomonas spp. The antibacterial activity was carried out on nutrient agar medium using disk diffusion method. The flavonoid fraction of root showed significant antibacterial activity against Staphylococcus aureus, Clavibacter michiganensis, Proteus vulgaris and Xanthomonas spp with 24, 25, 15 and $23 \mathrm{~mm}$ zone of inhibition respectively; followed by leaf flavonoid fractions with 22, 18, 19 and $20 \mathrm{~mm}$ zone of inhibition at $1000 \mu \mathrm{g} / \mathrm{ml}$ as compared to reference drug (streptomycin) having 27 , 26,26 and $26 \mathrm{~mm}$ at concentration of $0.5 \mu \mathrm{g} / \mathrm{ml}$ respectively. While ethanolic extract and other fractions showed dose dependent activities in order of highest root alkaloids < leaf alkaloids < leaf ethanolic extract and lowest by root ethanolic extract. MIC value confirmed that both alkaloids and flavonoids fraction were more potent than ethanolic extracts of root and leaves. The present study showed that $R$. succedanea have good significant antimicrobial potential against both gram positive and gram negative bacterial strains.

Key Words: Rhus succedanea; Antibacterial activity; Leaf and root; Ethanolic extracts; Disk diffusion method; Zone of inhibitions

\section{Introduction}

Rhus succedanea var. himalaica J. D. Hooker family anacardiaceae is a perennial small sized deciduous tree, grow up to height of 5-9 $\mathrm{m}$ tall, known locally by the name Sumac in English, Rakhkal in Pashto and Kakarsingi in Urdu. Rhus is an allergic plant due to presence of volatile oil Uroshiol and white latex. It causes a severe dermatitis when an allergic person comes in contact with. Rhus has imparipinnately and a highlybranched tape root system with yellow flower forming paniculate inflorescence [1].
Bacterial and fungal infections are responsible for many deaths, each year. The use of antibiotics has revolutionized the treatment of various bacterial and fungal infections. But due to resistance of microbes to antibiotics, it is necessary to assess natural plant resources for developing antimicrobial substances [2]. Plant secondary metabolites like alkaloids, flavonoids, tannins etc have natural antimicrobial properties [3]. Phytochemical natural antimicrobial agents are thought to be environment friendly, easily available and can be used as bio-control agents [4]. 
Phytoalexins from medicinal plants are naturally defensive compound for all kinds of living organism and helpful in treatment, prevention and control of multidrug resistance strains of bacteria and fungi extracted from medicinal plants [5]. In present research, the $R$. succadanea crude extracts were explored for antibacterial potential against different strains of bacteria.

Materials and methods

\section{Collection and preservation of plant}

The fresh root and leaf specimens of Rhus succedanea var. Himalica were collected from Shalmanay Kotkay, Disttrict Shangla, taken to the Department of Botany, University of Peshawar, where identification confirmed by Curator Mr. Ghulam Jelani. The Samples were air dried, mounted on Herbarium sheet and provided Voucher specimen number Bot. Khan, 2007 (PUP) and deposited in the herbarium.

Preparation of leaf and root ethanolic extracts

After pulverization of air dried root and leaf were grind through electric grinder and $1000 \mathrm{~g}$ powder was soaked in $6000 \mathrm{ml}$ of ethanol for 7 days in round bottom flask with continuous shaking the flask every day. The extract was then filtered and the solvent was evaporated through rotary vacuum evaporator and the remainder was transferred into petridishes and stored in refrigerator.

\section{Total alkaloids fraction}

$300 \mathrm{ml}$ of 10 percent acetic acids solution was added to the $10 \mathrm{~g}$ ethanolic extract of root and leaf in a beaker and kept for four hours, covered with aluminum foil. The solution was then concentrated to $1 / 4$ th of its original volume on water bath followed by the addition of concentrated $\mathrm{NH}_{4} \mathrm{OH}$. Precipitation occurred, which was filtered through Whatman filter paper, thoroughly washed with dilute ammonium hydroxide and the residues were collected as crude alkaloid [6].

\section{Total flavonoids fraction}

$10 \mathrm{~g}$ of each root and leaf extracts were dissolved in $200 \mathrm{ml}$ of methanol, containing $80 \%$ of aqueous solution, refrigerated for one night. On next day added chloroform to the solution (for glycosides flavonoids) drop after drop and transferred to a beaker, placed on water bath, evaporated to dryness and the remaining extract was the crude flavonoids $[3,7]$.

The antibacterial activity of leaf and root extracts as well as crude alkaloids and flavonoids fractions from both the parts of Rhus succedanea were carried against various strains of bacteria using disk diffusion method Figure 1. [4, 8].

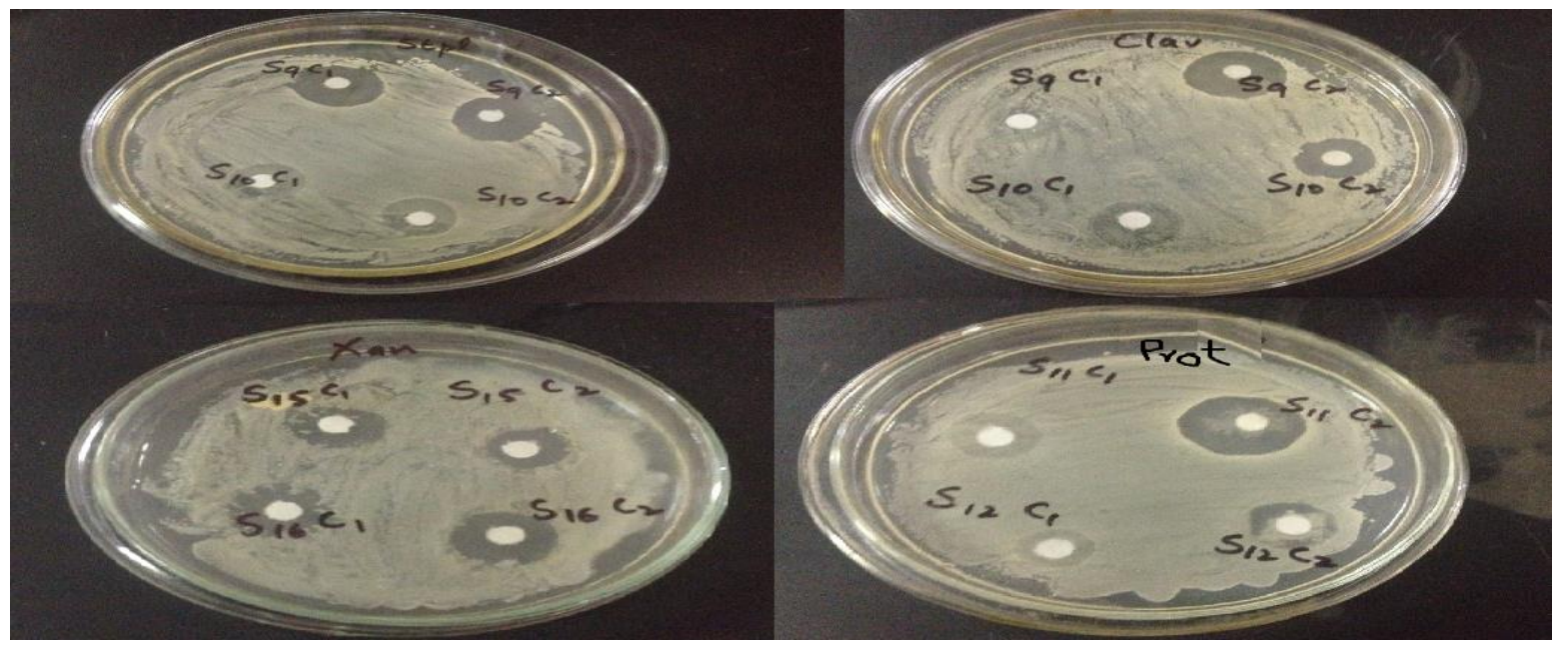

Figure 1. Antibacterial activity of $R$. succedanea against all the tested bacterial strains 


\section{Material needed}

Bacterial test organism, Nutrient agar, Plant extracts, plant alkaloids and flavonoids, petri dishes, distilled water, Autoclave, Laminar flow hood, Incubator, filter paper, cotton swab, Standard antibiotic (Streptomycin), and micropipettes.

Bacterial strains used; Gram-positive Staphylococcus aureus, Clavibacter michiganensis.

\section{Gram-negative}

Proteus vulgaris, Xanthomonas spp,

Procedure

Antibacterial activity of the test samples was carried out in research laboratory Agriculture University Peshawar. The Bacterial test organisms were cultured on nutrient broth and incubated for 24 hours before the start of experiments. Than the culture media was prepared by taking $20 \mathrm{~g}$ of Nutrient agar in $1000 \mathrm{ml}$ of distilled water and autoclaved at $137^{\circ} \mathrm{C}$ for 15 minutes and allowed to cool to $40^{\circ} \mathrm{C}$ and poured into previously sterilized petri dishes $(20 \mathrm{ml}$ to each petri dish) inside the laminar flow. Small circular desk of filter papers was transferred to the media and kept at equal distance. The bacterial strains were streaked on media through cotton swab. Than the test samples were dissolved in ethanol $20 \mathrm{mg} / \mathrm{ml}$ and applied at 10, 100 and $1000 \mu 1 / \mathrm{ml}$ dilution on filter paper desks. Ethanol and streptomycin were served as negative and positive control respectively. All the experiments were performed in triplicates. The petri dishes were than incubated at $37^{\circ} \mathrm{C}$ and antimicrobial effect was observed by zone of inhibition in mm after 24 hours.

Minimum inhibition concentration (MIC) MIC was calculated following method of [8, 9]. Extracts that exhibited inhibition at lowest dose $10 \mu \mathrm{g} / \mathrm{ml}$ were diluted further by the decreasing serial dilution to get the Minimum Inhibition Concentration.

\section{Results and discussion}

Chemist and pharmacist try to discover safe, economic and easily available substances from natural sources [9]. Plant extracts showing antimicrobial activity are a prospective source of innovative natural antimicrobial substances [10]. The antimicrobial activity of $R$. succedanea root and leaf extracts and their isolated crude alkaloid \& flavonoid fractions was carried out separately (Figure 1) the results were recorded as Mean and SEM in Table 1 and 2.

Table 1. Antibacterial activities (zone of inhibition in $\mathbf{m m}$ ) of ethanolic extracts, alkaloids and flavonoids of $\boldsymbol{R}$. succedanea Root against bacterial test organism

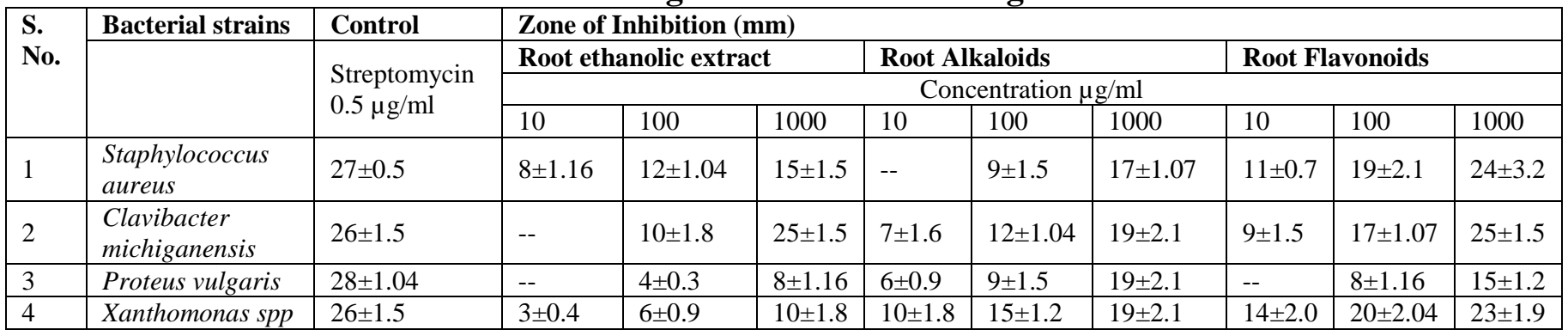


Khan et al.

Table 2. Antibacterial activity of (zone of inhibition $\mathbf{m m}$ ) ethanolic extracts, alkaloids and flavonoids of $R$. succedanea against bacterial test organism leaf

\begin{tabular}{|c|c|c|c|c|c|c|c|c|c|c|c|}
\hline \multirow{4}{*}{$\begin{array}{l}\text { S. } \\
\text { No. }\end{array}$} & \multirow[t]{4}{*}{ Bacterial strains } & \multirow{4}{*}{\begin{tabular}{|l|} 
Control \\
Streptomycin \\
$0.05 \mu \mathrm{g} / \mathrm{kg}$
\end{tabular}} & \multicolumn{9}{|c|}{ Plant parts } \\
\hline & & & \multicolumn{3}{|c|}{ Leaf ethanolic extract } & \multicolumn{3}{|c|}{ Leaf Alkaloids } & \multicolumn{3}{|c|}{$\begin{array}{l}\text { Leaf Flavonoids } \\
\end{array}$} \\
\hline & & & \multicolumn{9}{|c|}{ Concentration $\mu \mathrm{g} / \mathrm{ml}$} \\
\hline & & & 10 & 100 & 1000 & 10 & 100 & 1000 & 10 & 100 & 1000 \\
\hline 1 & $\begin{array}{l}\text { Staphylococcus } \\
\text { aureus }\end{array}$ & $27 \pm 0.5$ & $4 \pm 0.3$ & $14 \pm 2.0$ & $25 \pm 1.5$ & -- & $17 \pm 1.07$ & $20 \pm 1.99$ & -- & $11 \pm 0.7$ & $22 \pm 2.01$ \\
\hline 2 & $\begin{array}{l}\text { Clavibacter } \\
\text { michiganensis }\end{array}$ & $26 \pm 1.5$ & -- & $6 \pm 0.9$ & $9 \pm 1.5$ & -- & 11 & $15 \pm 1.5$ & -- & $8 \pm 1.16$ & $18 \pm 1.07$ \\
\hline 3 & Proteus vulgaris & $26 \pm 1.5$ & $9 \pm 1.5$ & $14 \pm 2.0$ & $21 \pm 2.01$ & -- & $10 \pm 1.8$ & $22 \pm 2.01$ & $4 \pm 0.3$ & $8 \pm 1.16$ & $19 \pm 2.1$ \\
\hline 4 & Xanthomonas spp & $26 \pm 1.5$ & -- & $8 \pm 1.16$ & $16 \pm 0.89$ & $15 \pm 1.5$ & $21 \pm 2.00$ & $23 \pm$ & $8 \pm 1.16$ & $16 \pm 0.26$ & $20 \pm 2.04$ \\
\hline
\end{tabular}

Roots extracts and its alkaloid and flavonoid fractions

The ethanolic extract of root showed 18, 12, $15 \mathrm{~mm}$ average zone of growth inhibition against $S$. aureus at doses of $10 \mu \mathrm{g} / \mathrm{ml}$, $100 \mu \mathrm{g} / \mathrm{ml}$ and $1000 \mu \mathrm{g} / \mathrm{ml}$ respectively as compared to the standard control Streptomycin, which showed $27 \mathrm{~mm}$ average zone of inhibition. While no inhibition was found against $C$. michiganensis and $P$. vulgaris at $10 \mu \mathrm{g} / \mathrm{ml}$. The lowest activity was also recorded at 100 and $1000 \mu \mathrm{g} / \mathrm{ml}$ with mean inhibition of 10,25 and $4,8 \mathrm{~mm}$ respectively compared with control 26 and $28 \mathrm{~mm}$ respectively. The root extract was least effective against Xanthomonas spp (Table 1).

The root alkaloids fraction showed no activity at $10 \mu \mathrm{g} / \mathrm{ml}$ while at 100 and 1000 showed 9 and $17 \mathrm{~mm}$ mean zone of inhibition. The alkaloids showed highest inhibition against Xanthomonas spp with mean 10, 15 and 19 zone of inhibition, while it moderately inhibited the growth of $P$. vulgaris and $C$. michiganensis at same concentrations shown in Table 1. The root flavonoids showed highly significant result against all the tested organisms (Table 1). The average zone of inhibition showed by flavonoids was $11,19,24 \mathrm{~mm}$ and 9,17 , $25 \mathrm{~mm}$ against $S$. aureus and $C$. michiganensis compared with the control 27 and $26 \mathrm{~mm}$ respectively. While it inhibited growth of $P$. vulgaris and Xanthomonas spp with $9,17,25 \mathrm{~mm}$ and $14,20,25 \mathrm{~mm}$ average zone of inhibition at the doses of 10,100 and $1000 \mu \mathrm{g} / \mathrm{ml}$ respectively (Table 1 ).

Leaf extracts and its alkaloid and flavonoid fractions

The ethanolic extract of leaf showed significant antibacterial activity against $S$. aureus and $P$. vulgaris showing average zone of inhibition of $4,14,25 \mathrm{~mm}$ and 9,14 , $21 \mathrm{~mm}$ at doses of 10,100 and $1000 \mu \mathrm{g} / \mathrm{ml}$ respectively comparing with the standard control streptomycin showing 27 and $26 \mathrm{~mm}$ average zone of inhibition. C. michiganensis and Xanthomonas spp growth was not inhibited at $10 \mu \mathrm{g} / \mathrm{ml}$ while at 100 and $1000 \mu \mathrm{g} / \mathrm{ml}$ showed lowest inhibition (Table 2).

The crude alkaloid and flavonoid fractions showed highly significant activity against Xanthomonas spp $(15,21$ and $23 \mathrm{~mm}$ average zone of inhibition) as compared to control (26mm). Leaf flavonoid showed moderate average growth inhibitory zone 4 , 8 and $19 \mathrm{~mm}$ against $P$. vulgaris, while $C$. michiganensis and $S$. aureus were least inhibited by both alkaloids and flavonoids fractions at all the respective doses (Table 2).

Minimum inhibition concentration (MIC) MIC value was assessed for those extract that possessed good antibacterial potential and maximum mean inhibition of bacterial growth. MIC is the lowest antibiotic concentration that inhibits visible growth of bacteria and used as a research tool for determination of in vitro activity of new antimicrobial 
substances. The MIC values range from $0.5 \mu \mathrm{g} / \mathrm{ml}, \quad 0.6(\mu \mathrm{g} / \mathrm{ml}), 0.7 \mu \mathrm{g} / \mathrm{ml}, 0.8 \mu \mathrm{g} / \mathrm{ml}$ that was exhibited by root and leaf alkaloids and flavonoids which were much similar to the standard drug Streptomycin followed by $1.0 \mu \mathrm{g} / \mathrm{ml}, \quad 2.0 \mu \mathrm{g} / \mathrm{ml}$ and $2.4(\mu \mathrm{g} / \mathrm{ml})$ exhibited by root and leaf crude ethanolic extracts Table 3. Among all the extracts the leaf flavonoids give good MIC values followed by root flavonoids Table 3 .

So it is observed from the above study and MIC determination that all the extracts exhibited have good antimicrobial potential against both gram positive and gram negative bacteria even at very low concentration. It is required to carry out advanced phytochemical work on $R$. succedanea to isolate the precise and specific antibacterial constituents and used as substitutes of synthetic antibiotic drugs.

Similar antibacterial activities were performed by earlier workers and reported results that are strongly in lineage with the present work like $[5,9,11]$ also reported that extracts and isolated compounds of Lawsonia inermis, Buddleja salviifolia Amaranthus viridis and Artemisia sieversiana showed highly significant antibacterial effect against various gram positive and gram negative. [12] reported Berberis baluchistanica, Iphiona aucheri, Ferula costata and Seriphidium quettense have mild antibacterial effect. Several other researchers like Pendota et al. [5], Rauha et al. [8], Essawi and Srour. [13], Chaudhary et al. [14] and Iqbal et al. [15] reported similar results for Posidonia oceanica, Salvia plebeian, Salvia cabulica, Geranium wallichianum, Acacia modesta, Colebrookea oppositifolia and suggested that the plant possess antimicrobial potential due the presence of several phytoconstituents like alkaloids, flavanoides, phenols, tannins, saponins, phlobatannins, sterols and alkaloids. Other Similar works were carried out by Adwan et al. [16], Kakar et al. [17], Bhalodia et al. [18], Hussain et al. [19] and Kalase et al. [20] which are in analogy with the present work. Our present report on $R$. succedanea plant also shows good antimicrobial potential, therefore, this has prominent perspectives in developing antimicrobial agents through further biological research.

Table 3. Minimum inhibition concentration value of ethanolic extracts, alkaloids and flavonoids of of $\boldsymbol{R}$. succedanea Root and leaf against bacterial test organism

\begin{tabular}{|l|l|l|l|l|l|l|l|l|}
\hline S.No & Bacterial strains & \multicolumn{6}{|c|}{ Zone of Inhibition (mm) } \\
\hline \multirow{2}{*}{} & & $\begin{array}{l}\text { Root } \\
\text { ethanolic } \\
\text { extract }\end{array}$ & $\begin{array}{l}\text { Root } \\
\text { Alkaloids }\end{array}$ & $\begin{array}{l}\text { Root } \\
\text { Flavonoids }\end{array}$ & $\begin{array}{l}\text { Leaf } \\
\text { ethanolic } \\
\text { extract }\end{array}$ & $\begin{array}{l}\text { Leaf } \\
\text { Alkaloids }\end{array}$ & $\begin{array}{l}\text { Leaf } \\
\text { Flavonoids }\end{array}$ \\
\cline { 3 - 8 } & & \multicolumn{6}{|c|}{ Minimum Inhibition Concentration value $(\mu \mathrm{g} / \mathrm{ml})$} \\
\hline 1 & $\begin{array}{l}\text { Staphylococcus } \\
\text { aureus }\end{array}$ & $1(\mu \mathrm{g} / \mathrm{ml})$ & ----- & $0.5(\mu \mathrm{g} / \mathrm{ml})$ & $2.4(\mu \mathrm{g} / \mathrm{ml})$ & ----- & $0.7(\mu \mathrm{g} / \mathrm{ml})$ \\
\hline 2 & $\begin{array}{l}\text { Clavibacter } \\
\text { michiganensis }\end{array}$ & ---- & $0.7(\mu \mathrm{g} / \mathrm{ml})$ & $0.5(\mu \mathrm{g} / \mathrm{ml})$ & ----- & ---- & $0.6(\mu \mathrm{g} / \mathrm{ml})$ \\
\hline 3 & Proteus vulgaris & ----- & $0.8(\mu \mathrm{g} / \mathrm{ml})$ & ----- & $1.2(\mu \mathrm{g} / \mathrm{ml})$ & ---- & $0.5(\mu \mathrm{g} / \mathrm{ml})$ \\
\hline 4 & Xanthomonas spp & $2.0(\mu \mathrm{g} / \mathrm{ml})$ & $1.2(\mu \mathrm{g} / \mathrm{ml})$ & $0.6(\mu \mathrm{g} / \mathrm{ml})$ & ----- & $0.8(\mu \mathrm{g} / \mathrm{ml})$ & $1.0(\mu \mathrm{g} / \mathrm{ml})$ \\
\hline
\end{tabular}

Conclusion and recommendations

Our present work concluded that the $R$. succedanea showed highly significant antibacterial activity against both gram negative and gram positive strains of bacteria. That revealed the presence of highly active antimicrobial phytoconstituents. So it is suggested and recommended that further advance and narrow work should be done on the present plant and the specific responsible agent should be identified, extracted and isolated, 
which will a reliable, economic and safe source of antibiotics instead of synthetic haphazard drugs.

\section{Author's contributions}

Conceived and designed the experiments: $\mathrm{M}$ Ibrar, Performed the experiments: SA Khan, Analyzed the data: S Ullah, Contributed reagents/ materials/ analysis tools: Barkatullah, Wrote the paper: SA Khan.

\section{References}

1. Khan SA, Ibrar M \& Barkatullah (2016). Pharmacognostic Evaluation of the Leaf of Rhus succedanea VAR. Himalaica. J. D HOOKER. Afr J Tradit Compl Altern Med 13(6): 107-120.

2. Shirsat R, Suradkar S \& Koche D (2014). Preliminary Phytochemistry and Antimicrobial Activity of Salvia Plebeia R. Br. and Colebrookea Oppositifolia Smith. Int J Pure Appl Sci Technol 20(1): 21-24.

3. Gislene GFN, Julian L, Paulo CF \& Giuliana LS (2009). Antibacterial activity of plant extracts and phytochemicals on antibiotic resistant bacteria, Braz $J$ Microbio 31: 247-256.

4. Nisha MC, Subramanian MS, Prathyusha P \& Santhanakrishnan R (2011). Comparative studies on antimicrobial activity of Artemisia sieversiana Ehrhart. Ex. Willd., and Origanum vulgare L. Int J Pharm Tech Res 2(2): 1124-1127.

5. Pendota SC, Aderogba MA, Ndhlala AR \& Staden JV (2013). Antimicrobial and acetylcholinesterase inhibitory activities of Buddleja salviifolia (L.) Lam. leaf extracts and isolated compounds. $J$ Ethnopharmacol 148: 515-520.

6. Koche DK, Kokate PS, Suradkar SS \& Bhadange DG (2012). Preliminary phytochemistry and antibacterial activity of ethanolic extract of Ocimum gratissimum, Bioscience Discovery 3(1): 20-24.

7. Berfad MA \& Alnour TMS (2014). Phytochemical analysis and Antibacterial activity of the 5 different extract from the seagrasses Posidonia oceanica. J Med Pl St 2(4): 15-18.

8. Rauha J, Remes S, Heinonen M, Hopia A, Kahkonen M, Kujala T, Pihlaja T, Vuorela M, \& Vuorela P (2000). Antimicrobial effects of Finnish plant extracts containing flavonoids and other phenolic compounds. Int J Food Micr 56: 3-12.

9. Barkatullah, Ibrar M, Muhammad N \& Feo VD (2015). Chemical composition and biological activities of the essential oil of Skimmia laureola leaves. Molecules 20: 4735-4745.

10. Seddik K, Nadjet I, Abderrahmane B, Daoud H \& Lekhmici A (2010). Antioxidant and antibacterial activities of extracts from Artemisia herba alba Asso. leaves and some phenolic compounds. J Med Pl Res 4(13): 1273280.

11. Rabou A, Yassin A, Al- Agha M, Madi M, Al-Wali M, Ali M \& Hamad D (2008). Notes on some common flora and its uses in Wadi Gaza, Gaza Strip. The Islamic University Journal 16(1): 31 $-63$.

12. Kavanagh, F (1963). Analytical Microbiology. (2nd Ed) Academic Press London pp.125-141.

13. Essawi T \& Srour M (2009). Screening of some Palestinian medicinal plants for antimicrobial Activity. J Ethnopharmac 70: 343-349.

14. Chaudhary G, Goyal S \& Poonia P (2015). Lawsonia inermis Linnaeus: A Phytopharmacological Review. Int. J Pharmaceut Sci Drug Res 10, 2(2): 91 98.

15. Iqbal MJ, Hanif S, Mahmood S, Anwar F \& Jamil A (2012). Antioxidant and antimicrobial activities of Chowlai (Amaranthus viridis L.) leaf and seed extracts. J Med Pl Res 6(27): 4450-4455. 
16. Adwan G., Abu-Shanab A \& Adwan, K (2010). Antibacterial activities of some plant extract alone and in combination with different antimicrobials against multidrug-resistant Pseudomonas aeruginosa strains. Asian Pac J Trop Med 25: 266-269.

17. Kakar SA, Tareen RB, Kakar MA, Jabeen H. Kakar SUR, Al-kahraman \& Shafee MM (2012). Screening of antibacterial activity of four medicinal plants of Balochistan Pakistan. Pak J Bot 44: 245-250.

18. Bhalodia R. Nayan \& Shukla VJ (2011). Preliminary phytochemical screening and In Vitro antioxidant potential of stem extract of Cassia fistula L. Int J Pharm Inno 1(2): 35-41.

19. Hussain AL, Anwar F, Sheraz STH \& Przybylski R (2010). Chemical composition, antioxidant and antimicrobial activities of basil (Ocimum basilicum) essential oils depends on seasonal variations, Food Chemistry 108: 986-995.

20. Kalase V, Heinonen $M$ \& Jadhav V (2010). Preliminary phytochemical and antibacterial studies on leaf and bark of Holigarna grahamii (Wight) Kurz. (Anacardiaceae). J App Pharm Sci 3(6): 111-113. 